\title{
Performance Analysis of Saving and Credit Cooperatives "Case Study: KSP / KSU in Gowa Regency"
}

\author{
Sahade \\ Pendidikan Akuntansi, Fakultas Ekonomi, Universitas Negeri Makassar \\ Email: sahade@unm.ac.id
}

\begin{abstract}
The purpose of this study was to determine the performance of savings and loan cooperatives in Gowa Regency and the magnitude of the influence of the quality factors of productive assets, capital, profitability, and liquidity both partially and simultaneously on the performance of KSP/USP in Gowa Regency. This research uses quantitative research because the data used in this study are quantitative data. Research data which is secondary data concerning the quality of productive assets, capital, profitability and liquidity from $41 \mathrm{KSP} / \mathrm{USP}$ financial statements in Gowa Regency that have carried out consecutive RATs during 2008 through documentation data collection techniques. The data is analyzed using multiple linear regression and financial ratios. The results of the KSP/USP financial ratio analysis in Gowa Regency were quite healthy. While the results of multiple linear analysis of the factors of quality of productive assets, capital, profitability, and liquidity by simultaneous or partial test have a significant effect on cooperative performance. The effect of the four factors analyzed is very strong, which is in the range of coefficient values of $0.80-1.00$, and the magnitude of the influence of these four factors on the performance of KSP / KSU in Gowa Regency is 99.80 percent.
\end{abstract}

Keywords: Cooperative Performance; KSU, Remaining Operating Results (SHU).

\section{INTRODUCTION}

Cooperatives play an important role in carrying out their activities, for the realization of an economic system that ensures equitable distribution of development results, both for people who are members of cooperatives and for members of the community in general. The business field of the cooperative reflects the type of service offered to its customers. The business sector of cooperatives, especially savings and loan cooperatives / savings and loan units, are cooperatives engaged in the accumulation of capital savings from their members, to then be lent back to members who need capital assistance. The cooperative aims to educate its members to be frugal, and likes to save money (Aumarm, 2016; Hadfield-Menell et al., 2016). KSP / USP cooperatives also aim to be able to free members from the bondage of moneylenders / middlemen, by saving and obtaining capital from their own cooperatives, members of a savings and loan cooperative unit will not only enjoy the results of their savings and cooperative business results but they will also has the opportunity to make capital searches at low cost (Ning et al., 2019; Pahlavanhoseini \& Sepasian, 2019; Ren et al., 2017; Zhuang et al., 2019).

The assessment of cooperative health predicate is very important, both the government and the cooperative manager (the members) themselves, so the results of the health assessment 


\section{Jurnal Administrare: Jurnal Pemikiran Ilmiah dan Pendidikan Administrasi Perkantoran Vol. 7, No. 1, January - June 2020, Pages 93-108}

predicate aim to assess the performance of the KSU / USP by looking at the quality factors of productive assets, capital, liquidity and profitability of the cooperative, and see the extent of the ability KSP / USP maintains its business continuity. A healthy KSP / USP will provide many benefits for both the government and the managers themselves. The advantage referred to from the government side is that business is relatively certain to improve the welfare of the community in general (Farida et al., 2017; Markovic et al., 2020; Rengifurwarin et al., 2018; Zhang et al., 2019; Zhou \& Wen, 2020). From the manager's side of the cooperative, the benefits can be in the form of increasing the welfare of members, with the availability of funds / capital for members or Remaining Business Results (SHU) received by its members and so on.

The granting of health status in the KSU / USP business is that it is not impossible that a cooperative declared healthy by the government can provide a level of welfare for its members as referred to above. Likewise, the security of funds / capital through members' savings because there is no guarantee that the loan will not be bad (bad credit).

Efforts to develop economic potential are usually carried out with many things both in coaching and in various forms of involvement. In this case the cooperative is expected to be able to play an active role in the sense of participating in mental development, institutional and cooperative efforts. Therefore, the government has stipulated regulations in this case the development and evaluation or examination of cooperatives. These stipulated provisions govern whether a cooperative organization that is still operating is in accordance with the rules of the game and or a healthy cooperative and has fulfilled the criteria for independence of a cooperative that is able to overcome all its own problems.

Specifically in the business sector, because cooperatives are a business entity that is more or less involved in the economic field, then in finding solutions to problems related to capital, asset quality, profitability and liquidity, knowledge of economic principles will be needed (Iskandar \& Partadiredja, 1995). This means that cooperatives in conducting their business cannot leave the nature and economic requirements to achieve efficiency, because cooperatives are in a business environment (business environment) in which there are other forms of companies that are equally trying to explore the potential of existing resources.

It must be recognized that to develop cooperatives as well as expected, the management must be good too. This means that cooperatives cannot stand tall and strong without good and healthy management. Cooperatives are demanded this way because their position today is not only pursuing the principles of kinship and cooperation but needs to carry out its functions for the welfare of members. The connotation is that although cooperatives are not a collection of capital but must have capital to develop or in other words, cooperatives do not aim to pursue profits but are expected to obtain profits to develop in the future. The expectation of obtaining profits in the future is inseparable from efforts to efficiently use capital and manage productive assets in the cooperative itself, because the higher level of efficiency will ultimately lead cooperatives to achieve profitability and good liquidity.

Initial observations in this study indicate that the growth rate of savings and credit cooperative units in Gowa district in 2006/2007 increased by $12 \%$ from 146 cooperatives in 2005/2006, to 166 savings and loan cooperatives spread across 18 sub-districts and registered with the Department of Cooperatives and Gowa district UKM, in fact only 65 savings and loan cooperatives are classified as "healthy cooperatives".

Seen from an institutional standpoint, the development of savings and loan cooperatives in Gowa district is very rapid, but from the quality of the activities of the KSU / USP as an 
economic institution aimed at the welfare of its members, it is still very weak. This happens because of the many factors that influence, among others, internal control system factors that aim to: (1) secure cooperative assets, (2) test the accuracy and correctness of accounting data, (3) increase operating efficiency, and (4) adherence to policies the wisdom outlined by the leadership. Other factors that are not less important are capital, quality of productive assets, liquidity and profitability of cooperatives. The problem is whether other cooperatives do not meet the criteria set by the government so they are not classified as healthy and whether the capital factor, the quality of productive assets, liquidity and profitability are the factors that determine the level of cooperative effort.

\section{METHOD}

This research uses explanatory survey method. The explanatory survey according to Masri \& Effendi (1995), is a research that explains the relationship between variables. While the type of research conducted is descriptive-verification research (descriptive-verification research), with cross sectional techniques. The object of this research is KSP / USP in Gowa Regency. With the aim of obtaining empirical evidence regarding the influence of productive asset quality, capital, profitability and liquidity on the performance of KSU / USP.

This study consists of two types of variables, namely the independent variable which is given the symbol $\mathrm{X}$ and the dependent variable which is given the symbol $\mathrm{Y}$. For more details, it can be seen in the explanation in table 1.

Table 1

Measurement of Research Variables

\begin{tabular}{|c|c|c|c|}
\hline Variable & Dimension & Indicator & Scale \\
\hline 1. Capital (X 1 ) & $\begin{array}{l}\text { 1. source of capital } \\
\text { 2. use of capital }\end{array}$ & $\begin{array}{l}\text { own capital against } \\
\text { loans given is risky }\end{array}$ & Ratio \\
\hline $\begin{array}{l}\text { 2. Quality of productive } \\
\text { assets }\left(\begin{array}{l}\mathrm{X}_{2} \\
2\end{array}\right)\end{array}$ & $\begin{array}{l}\text { 1. loan volume } \\
\text { 2. risk of non-performing } \\
\text { loans } \\
\text { 3. risk reserves }\end{array}$ & $\begin{array}{l}\text { 1. risk of non- } \\
\text { performing loans to } \\
\text { loans } \\
\text { 2. reserve risk against } \\
\text { problem loans }\end{array}$ & Ratio \\
\hline 4. Profitability (X3) & $\begin{array}{l}\text { 1. SHU } \\
\text { 2. Operating income } \\
\text { 3. Operational expenses } \\
\text { 4. Total assets }\end{array}$ & $\begin{array}{l}\text { 1. SHU before tax on } \\
\text { total assets } \\
\text { 2. Load operation of } \\
\text { the revenue } \\
\text { operations }\end{array}$ & Ratio \\
\hline 4. Liquidity (X4) & $\begin{array}{l}\text { 1. Loan } \\
\text { 2. Fund }\end{array}$ & $\begin{array}{l}\text { Loans given to funds } \\
\text { received }\end{array}$ & Ratio \\
\hline $\begin{array}{l}\text { 5. Cooperative } \\
\text { Performance }(\mathrm{Y})\end{array}$ & $\begin{array}{l}\text { 1. Capital }(30 \%) \\
\text { 2. Quality of productive } \\
\text { assets }(35 \%) \\
\text { 3. Profitability }(20 \%)\end{array}$ & $\begin{array}{l}\text { 1. Healthy } \\
\text { 2. Healthy enough } \\
\text { 3. Unwell } \\
\text { 4. Not healthy }\end{array}$ & Ratio \\
\hline
\end{tabular}


96 Jurnal Administrare: Jurnal Pemikiran Ilmiah dan Pendidikan Administrasi Perkantoran
Vol. 7, No. 1, January - June 2020, Pages 93-108

4. Liquidity (15\%)

The data used is collected in various ways, namely; observation, interview and documentation. Data needed in this study are:

1. Primary Data, i.e. data obtained directly from the research location through interviews with cooperative management and members to obtain data based on indicators measured from each cooperative spread in 7 (seven) districts of 18 districts in Gowa district which are locations research.

2. Secondary data, i.e. data obtained from relevant agencies (Office of Cooperatives and SMEs) and data on 2008 cooperative financial statements related to this study.

The target population in this study were all cooperatives registered at the Gowa Regency Cooperative and SME Office of 166 cooperatives. This study took the sample with the largest minimum sample size (Creswell, 2013), with a degree of confidence of 95\%. Determination of sample size using the following formula:

Information :

$$
n=\frac{N \cdot Z^{2} \cdot p q}{d^{2}(N-1)+Z^{2} \cdot p \cdot q}
$$

$\mathrm{n}=$ Sample size

$\mathrm{N}=$ Large population (166 KSU / USP)

$\mathrm{p}=$ Proportion of total KSU / USP $=(0.5)$

$\mathrm{q}=1-\mathrm{P}=1-0.5=0.5$

$\mathrm{D}=$ The level of accuracy used is 0.1

$\mathrm{Z}=$ Standard deviation, used 1.96 according to the $95 \%$ significance level.

$$
\begin{aligned}
& \mathrm{n}=\frac{166 \cdot 1,96^{2} \cdot 0 \cdot 5 \cdot 0 \cdot 5}{0.1^{2}(166-1)+1 \cdot 96^{2} \cdot 0 \cdot 5 \cdot 0 \cdot 5} \\
& \mathrm{n}=\frac{159,43}{2,61} \\
& \mathrm{n}=61,07 \approx 61 \mathrm{KSP} / \mathrm{USP}
\end{aligned}
$$

The results of the calculation obtained a sample number of 61 KSP / USP in Gowa Regency, but only those who carried out the management accountability report or the Annual Member Meeting (RAT) in 2008 amounted to 41 cooperatives so that the data were sampled. The sample locations in the study are presented in table 2 . 
Table 2

Location and number of research samples

\begin{tabular}{|c|c|c|}
\hline No. & 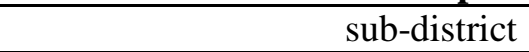 & Number of KSU / USP \\
\hline 1 & Somba Opu & 15 \\
\hline 2 & Palangga & 9 \\
\hline 3 & Tompobulu & 4 \\
\hline 4 & Bompompo & 4 \\
\hline 5 & Bajeng & 4 \\
\hline 6 & High bells & 3 \\
\hline 7 & Barombong & 2 \\
\hline \multicolumn{2}{|r|}{ total } & 41 \\
\hline
\end{tabular}

Based on the research paradigm and operational definitions of the variables studied. To test the hypothesis that has been proposed, the following analysis is performed:

1) Financial ratio analysis used in this study are:

- Cooperative capital ratio,

- The ratio of the quality of productive assets of cooperatives,

- Cooperative profitability ratios, and

- Cooperative liquidity ratio

2) multiple linear regression analysis using SPSS 11.0 for Windows (Statistical Peckage for Social Science) program. The regression equation can be formulated as follows (Supranto, 2000):

$\hat{\mathrm{Y}}=\beta 0+\beta 1 \mathrm{X} 1+\beta 2 \mathrm{X} 2+\beta 3 \mathrm{X} 3+\beta 4 \mathrm{X} 4+\mathrm{e}$

Where:

$\hat{Y}$ : Cooperative performance

X1: Capital

X2: Quality of productive assets

X3: Profitability

X4: Liquidity

$\beta 0$ : Constants

$\beta \mathrm{i}$ : Coefficient of regression direction $\beta 1, \beta 2, \beta 3, \beta 4$

With the hypothesis proposed as follows:

$\mathrm{H} 0: \beta \mathrm{i}=0$

$\mathrm{H} 1: \beta \mathrm{i} \neq 0$

Where $\beta \mathrm{i}=\beta 1, \beta 2, \beta 3, \beta 4$

$\mathrm{H} 0: \beta 1, \beta 2, \beta 3, \beta 4=0$

$\mathrm{H} 1: \beta 1, \beta 2, \beta 3, \beta 4 \neq 0$

With a significant level that is used, namely $\alpha=0.05$. To test this hypothesis. Data analysis carried out to test the hypothesis of this research will be carried out with the help of the SPSS 11.0 computer program package for Windows. After the statistical test results are known, a statistical decision is made which is marked by acceptance or rejection of the hypothesis. In addition to statistical analysis descriptive analysis is also explained to provide an explanation of the statistical decisions made, so that correct conclusions can be drawn. 
98 Jurnal Administrare: Jurnal Pemikiran Ilmiah dan Pendidikan Administrasi Perkantoran

Vol. 7, No. 1, January - June 2020, Pages 93-108

\section{RESULT AND DISCUSSION}

Along with the increase in population that occurs from year to year is also accompanied by the development of the number of cooperatives that are also increasing. The conditions of cooperatives from 2006 to 2009 were spread in 18 Sub-districts in Gowa Regency in table 3.

Table 3

Development of Cooperatives in Gowa Regency in 2006 - 2009.

\begin{tabular}{cccc}
\hline No. & Year & Number of cooperatives & Growth $(\%)$ \\
\hline 1 & 2006 & 345 & - \\
2 & 2007 & 355 & 1.03 \\
3 & 2008 & 373 & 1.05 \\
4 & 2009 & 415 & 1.11 \\
\hline
\end{tabular}

Source: Gowa Regency Cooperatives \& SMEs Service, 2009.

Based on table 3 it appears that each year the number of cooperatives in Gowa Regency continues to increase. The increase in the number of cooperatives shows that the people of Gowa Regency have a high awareness of the importance of the existence of cooperatives in the region as a pillar of the economy in favor of the small people as a basis for people's economy in increasing development in the region, especially in improving the welfare of the community as a forum for helping and facilitating the community, both in terms of business capital assistance and in terms of marketing the results of the production of community crafts as their built business.

The development of cooperatives in Gowa Regency is also inseparable from the increase in small businesses as fostered businesses in each region in each sub-district / village / village which is a government program for empowering small communities in utilizing the resources in the village / village, and encourage the community to explore the potential of rural communities and the potential of natural resources in the area to be utilized maximally and efficiently so as to improve the welfare of the community equally so that there is no imbalance between villages and cities.

\section{Data Analysis Results}

There are various opinions about the category of ratio based on the purpose of analyzing in evaluating a cooperative based on its financial statements. According to Schall \& Haley (1980) that financial ratios can be classified into 4 categories, Of the ratios used as financial statement analysis tools, in this study only the related ratios will be analyzed with cooperative performance in accordance with the topic.

Based on the financial statement data sourced from the balance sheet and the residual report of the results of the 2008 RAT business from 41 the number of savings and loan cooperatives and savings units sampled in this study, the data was obtained from the Gowa Regency Cooperative and SME Office and the savings and loan cooperatives and units savings and loans, it can be analyzed regarding capital ratios, asset quality ratios, profitability ratios and liquidity ratios. The analysis used is as follows. 


\section{Financial Ratio Analysis}

\section{a. Capital Ratio Analysis}

From the capital aspect of KSP / USP in Gowa Regency, it has been very good in maintaining and maintaining the continuity of cooperative business activities, because large capital does not necessarily guarantee a business can run well as well as small capital but how can existing capital be managed in a manner efficient and effective for business continuity and member welfare.

This is important because if the capital owned is too large it means that some funds are unemployed and this will reduce the level of profitability of the cooperative business. Likewise, if the capital is too small, there will be a risk that the cooperative's savings and loan activities may be disrupted and not distributed to all existing members.

In the business world it is common to sell goods and services on credit to customers, the existence of credit sales means that the company has not obtained or made cash (cash) at the time of delivery of these goods and services to customers who tangible in the form of receivables. Credit sales activities in the form of goods or services is a way to advance the business activities of a company to achieve a certain target regarding the number of sales in a certain period, which in turn is a profit or the amount of profit to be obtained, but on the other hand faces various possibilities can hinder the achievement of the company's main goals in terms of working capital turnover for business continuation.

On the other side of the sale of credit, the emergence of receivables which are claim rights in the form of money owned by the company against a person or company. Accounts receivable is the amount of money that exists at the party who buys goods or services (services that have been provided by the company) without making payments in cash and is obliged to pay it at a time agreed upon between the seller and the buyer.

Technically KSP / USP in Gowa Regency is more careful in providing credit loans to customers because their capital is really intended to finance business operational activities and to be distributed to members who need it, even though to increase sales volume, most Large companies sell their products on credit. However, credit sales do not immediately generate cash receipts, but give rise to accounts receivable, and only then on the day of payment does cash flow occur from the collection of these receivables, thus receivables are an element of capital that is always in the capital turnover chain for the survival of the cooperative. However, there are still KSP / USP which have very large amounts of receivables. This is because the KSP / USP also has a very large and broad number of members.

The ratio of the ratio of own capital to the number of loans given to customers (receivables) multiplied by 100 shows an excellent ratio of 81 percent and above and an average capital ratio of 85 percent. This means that the capital owned by KSP / USP is used efficiently and effectively so that there are no idle funds or unused funds and all existing receivables can be collected according to the time period given to customers. Trust and awareness of the community to utilize cooperatives as financial institutions other than banks to be used as a place to save / store their funds to be used in cooperative activities so as to provide welfare for its members. This also shows that KSP / USP managers (managers and administrators) are wiser in making decisions regarding the progress of the cooperatives they lead. 


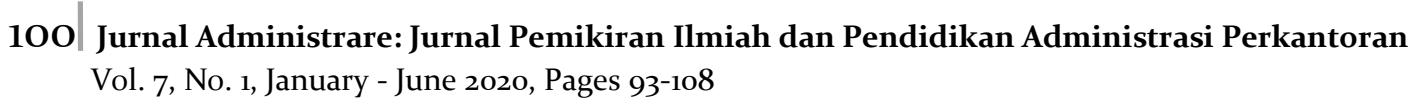

This high capital ratio, is also based that the longer the capital-binding period will increase the amount of capital requirements, and vice versa if the capital-binding period the smaller the capital requirements will also be smaller. The capital binding period for service businesses is usually lower than for industrial companies. In a service company, the bound period of the funds starting from the cash is given to the applicant member who will then become a receivable and after the receivables are paid, it will become cash again. The length of the collectible receivables is the period of bound for working capital so that it can affect the continuity of the cooperative.

From the above capital ratio, then the overall capital ratio of cooperatives used in assessing cooperative performance with a total score of 30 percent is the highest ratio among other ratios that are used as the basis for valuation. Thus, from the results of the capital ratio analysis, the KSU / KSP in Gowa Regency are quite healthy (22.71 percent).

\section{b. Earning Asset Ratio Analysis}

Cooperative is a business entity that is expected to become a pillar of the economy is largely determined by the ability or independence to be implemented to respond to challenges and threats. While seen from its function, cooperative strength is measured by its ability to develop and dominate the market and provide rational alternatives for customers (members) through various business incentive policies and improvements in customer service (member) techniques.

Therefore, the quality of assets held as a means and infrastructure that is important in carrying out cooperative business activities should be used and used productively so that these assets can rotate quickly within one year.

The assessment of earning asset quality is based on 2 (two) ratios, namely: 1) the ratio between the risk of non-performing loans and loans granted, and 2) the ratio between risk reserves and non-performing loans.

The risk of loans given to members in the form of receivables is very small although there is still a small portion of the loan value that is large enough for members who need venture capital by only looking at collateral (collateral) in the form of land certificates, houses and BPKB vehicles with a period of between 4-5 years without considering the profitability of the business and their ability to repay the loan according to maturity so the risk of repayment is large.

Therefore, loans provided to members are very effective, so that existing funds can be channeled properly and the risk of not returning small funds. This is that the KSP / USP managers / leaders / administrators in Gowa Regency have succeeded in applying the principles of lending called 4C, namely character; capacity (ability); capital (capital); colleteral (guarantee); and condition (place of business \& economic conditions) so that the risk of loans that occur is very small and the quality of assets owned is very productive to be able to cash back.

With a small loan risk, the capital reserve becomes smaller. This is based on the capital reserves of each cooperative depending on the size of the existing loan risk.

Existing capital reserves depend on the size of the risk of bad loans and working capital needs that must be available. Because the risk of existing loans is small because the funds channeled can be returned according to maturity and the capital used can rotate for a period well 
(from capital-supply-capital receivables). Therefore, that KSU / KSP uses existing funds to be used to finance cooperative operations in accordance with the line of business it runs, so that the quality of existing assets is used effectively and efficiently.

Of the two earning asset quality ratios above, the overall earning asset quality ratio used in assessing cooperative performance with a total score of valuation of 35 percent of the ratio of earning assets. Thus the ratio of the quality of productive assets of the cooperatives obtained from the analysis results is 25.17 percent, then the KSU / KSP in Gowa Regency are categorized quite healthy.

\section{c. Analysis of Profitability Ratios}

In its activities every company has the same goal, which is to obtain profits to ensure the survival of the company. It often happens that a company has succeeded in making a profit or profit in its operational activities, but the company has not developed as expected. The level of profit achieved is not a measure of whether a company is able to work well. There are companies that in a period have obtained a large profit but the profits obtained are not balanced with the amount of funds invested to get these benefits.

To be able to interpret the company's ability to obtain the benefits to be achieved, namely by using the profitability ratio. Profitability itself is the ability of a company to benefit from the use of funds during the accounting period. The quantitative assessment of cooperative profitability is based on 2 (two) ratios namely; 1) the ratio of SHU before being taxed to total assets, and 2) operating expenses to operating income. Based on the financial statements of the results of the 2008 RAT, an analysis of the profitability of cooperatives is carried out.

The Remaining Ratio of Operating Results (SHU) to total assets is in the sufficient category. This means that all assets owned by KSP / USP as a whole are able to contribute to the acquisition of SHU on average by 87 percent which is in the good category. Thus the KSU / KSP in Gowa Regency can be said that the success of a KSP / USP is largely determined by the level of business efficiency.

To find out you have to compare the profits obtained with the capital used. For companies in general the problem of profitability is more important than the problem of profit, because even large profits are not a measure that the company has worked efficiently, because the new efficiency can be known by comparing the profits obtained with the wealth or capital used. Therefore, the high or low level of profitability achieved by a company in a certain time generally depends on the efficient use of funds invested to make a profit. The higher the level of profitability achieved by the company the better so it can facilitate the acquisition of external funds from creditors or lenders.

Furthermore, to find out how much the efficiency of utilization of assets (operational costs) to the income of cooperative businesses, it can be seen the ratio of operating costs to operating income. Operational costs incurred by KSU / KSP in Gowa can be saved by 50 percent. Therefore, KSU / KSP in Gowa Regency can provide welfare to members with substantial income. Because with the small costs and operational activities of the cooperative as it should be in accordance with the rules and financing that should be done, the operating income of the business will increase.

From the two profitability ratios above, the overall profitability of cooperatives used in assessing cooperative performance with a total score of 20 percent. Thus, from the results of the 


\author{
102 Jurnal Administrare: Jurnal Pemikiran Ilmiah dan Pendidikan Administrasi Perkantoran \\ Vol. 7, No. 1, January - June 2020, Pages 93-108
}

analysis of profitability ratios obtained an assessment of 12.11 percent, the KSU / KSP in Gowa Regency are quite healthy.

\title{
d. Liquidity Ratio Analysis
}

Liquidity problems are problems that relate to the ability of a business to meet its financial obligations which must immediately be met. The amount of payment instruments (liquid instruments) owned by a company at any given time is the paying power of the company concerned. Corporate finance can be said to be liquid if in addition to being able to run daily business, it can also pay off debts that are due.

Based on the results of the analysis explained that the funds received from members and non-members can be managed properly can also be returned within the agreement period. These funds can also be returned for members who will withdraw funds at any time so that KSP / USP can guarantee these funds to be returned to members of savers with an availability of funds up to 80 percent of the funds received.

Thus, that KSP / USP in Gowa Regency has a very smooth rate of repayment of loans to members of savers. This means that they are able to provide funds for loans received by 2: 1 or Rp. 1 loans available with funds of Rp. 2 so that the business continuity of cooperatives runs smoothly and public trust is also increasing and cooperatives that have been considered as not a place to store public funds are broken.

The liquidity ratio above, the overall cooperative liquidity used in assessing the performance of cooperatives with a total score of 15 percent. Thus, from the results of the analysis of the liquidity ratio, an assessment result of 14 percent was obtained, so that the KSU / KSP in Gowa Regency was categorized as healthy.

The results of the analysis of the four factors that affect cooperative performance from 41 KSP / USP financial statement data, then based on the results of the analysis of the four ratios with an assessment score of 30 percent capital; 35 percent of the quality of productive assets, 20 percent of profitability and 15 percent of liquidity obtained a total score of 75 percent. Thus, the acquisition of the score KSP / USP in Gowa Regency was stated to be quite healthy.

\section{Analysis of multiple linear regression and hypothesis testing}

One of the objectives of this research is to find out which factors have an influence on the performance of KSP / USP in Gowa Regency. In this study also will be analyzed in more depth which factors have a significant contribution to the performance of KSP / USP in Gowa Regency.

This study consists of four independent variables, namely capital (X1), quality of productive assets (X2), profitability (X3), and liquidity (X4). While the dependent variable in this study is cooperative performance (Y). The data to be analyzed for each of these variables meets the requirements for analysis using inferential statistical analysis tools, namely multiple linear regression. The analysis was carried out using the SPSS 11.0 for Windows (Statistical Check for Social Science) program. The results can be seen as summarized in the following table.

Table 5 shows a summary of the results of multiple linear regression analysis through the SPSS 11.0 for Windows (Statistical Check for Social Science) program. Based on the table, it 
appears that the magnitude of the correlation coefficient ( $\mathrm{r}$ ) is 0.999 . Based on the table of interpretations of the correlation coefficient (r) stated earlier, the influence between capital (X1), quality of productive assets (X2), profitability (X3), and liquidity (X4) on the performance of KSP / USP in Gowa Regency has a category or a very strong relationship level is in the coefficient interval $0.80-1.00$.

Table 4

Summary of the results of multiple linear regression analysis

\begin{tabular}{lccccc}
\multicolumn{1}{c}{ Iabel Var } & $\beta$ & $\mathrm{F}_{\text {count }}$ & $\mathrm{S}$ ig. & $\mathrm{t}_{\text {count }}$ & $\mathrm{S}$ ig. \\
\hline A constant & 1,363 & & & .709 & .483 \\
Capital & 1,016 & & & 80,150 & 0,000 \\
Asset Quality Prod. & 0.936 & 4997,454 & 0,000 & 11,765 & 0,000 \\
Profitability & 1,010 & & & 61,006 & 0,000 \\
Liquidity & .978 & & & 23,765 & 0,000 \\
\hline$\alpha: 0.05 \mathrm{R}^{2}: 0.998$ & \multicolumn{3}{c}{} \\
r: 0,999 & BC: $0,998 \times 100 \%=99.8 \%$ & \\
\hline
\end{tabular}

Source: 2009 data processing results

Furthermore, the coefficient of determination R2 (R square) is equal to 0.998 or 99.8 percent. This means that increasing or decreasing the KSP / USP performance assessment score in Gowa Regency, 99.8 percent is contributed by capital (X1), earning asset quality (X2), profitability (X3), and liquidity (X4), while the remaining 0,2 percent is the contribution of other variables that are not used in this study. This is due to the fact that among the five factors used in evaluating cooperative performance, four factors have been included in the research variable, only management factors are not included because management factors are used to assess the health of the administration, while the four factors studied look at being healthy in business.

Based on the table above it can also be seen the value of the multiple linear regression equation between capital factors, the quality of productive assets, profitability and liquidity on the performance of KSP / USP in Gowa Regency. The value of the regression equation is as follows.

$\hat{\mathbf{Y}}=\boldsymbol{\beta}_{0}+\beta_{1} \mathbf{X}_{1}+\beta_{2} \mathbf{X}_{2}+\beta_{3} \mathbf{X}_{3}+\beta_{4} \mathbf{X}_{4}+\beta_{5} \mathbf{X}_{5}+e$

$\hat{Y}=1,363+1,016\left(X_{1}\right)+0,936\left(X_{2}\right)+1,010\left(X_{3}\right)+0,978\left(X_{4}\right)+e$

Coefficient $\beta 0$ or a constant of 1.363 states that before the presence of capital factors (X1), the quality of productive assets (X2), profitability (X3), and liquidity (X4)) or X1, X2, $\mathrm{X} 3$, and X4 $=0$, the performance appraisal score KSP / USP in Gowa Regency has shown an assessment score of 1.363 percent. Furthermore, the magnitude of the value of the regression coefficient $\beta 1$ shows a positive value of 1.016 . This means that every time there is an increase in capital by 1 percent, there will be an increase in the score of cooperative performance appraisal of 1.016 percent.

Likewise, the magnitude of the value of the regression coefficient $\beta 2$ which shows a positive value of 0.936 . This means that an increase in the quality of productive assets by 1 percent will have an impact on an increase in the cooperative performance appraisal score of 


\author{
104 Jurnal Administrare: Jurnal Pemikiran Ilmiah dan Pendidikan Administrasi Perkantoran \\ Vol. 7, No. 1, January - June 2020, Pages 93-108
}

0.936 percent. Furthermore, the value of the regression coefficient $\beta 3$ also shows a positive value of 1.010. This value indicates that an increase in profitability of 1 percent will have an impact on an increase in the cooperative performance appraisal score of 1,010 percent.

The coefficient of the regression direction $\beta 4$ shows a positive value of 0.978 . This shows that an increase in liquidity of 1 percent will result in an increase in the KSP / USP performance assessment score in Gowa Regency by 0.978 percent.

The above description is an interpretation of the constant value and the coefficient of the regression direction from the regression equation model of the factors that affect the performance of KSP / USP in Gowa Regency.

Based on the results of data processing through the SPSS 11.0 for Windows (Statistical Peckage for Social Science) program, the Durbin-Watson (DW) value of 1,800 was found. While from the DW table (contained in the appendix) with the number of samples $(n=41)$ and $\mathrm{k}=4$ at a significant level of 0.05 a value of 0.792 was obtained. From this it can be seen that the Durbin-Watson (DW) value of 1.800> 0.792 so that it can be stated there is no autocorrelation problem. From testing the classical assumptions above, it appears that no classic assumption deviations occur, both deviations from multicollinearity, heteroscedasticity and autocorrelation, so that the regression equation model used in this study can be declared statistically feasible.

\title{
Discussion
}

These results, explained that in general capital, the quality of productive assets, profitability and liquidity do have an important role on business continuity, especially cooperative business. Because cooperatives are clearly business entities, which must therefore pay attention to generally accepted business rules (Galor \& Sofer, 2019; Iliopoulos et al., 2019; Jensen-Auvermann et al., 2018). But besides that also, as a business entity in the form of a cooperative it must also be able to base its activities on the values and principles of cooperatives that are held in high esteem and are universally adhered to. In order for a cooperative to continue to exist and survive as a business entity in the midst of society, it cannot avoid the generally accepted business rules, so that adequate capital is required, the management and use of funds (quality of productive assets) that are owned efficiently and the availability of funds to guarantee the repayment of loans as soon as possible to be paid (the level of liquidity) so as to be able to generate profits or the remaining business results (SHU) with funds and capital owned for the welfare of members.

To determine the cooperative can get the title of healthy, healthy enough, less healthy, and unhealthy, then the measurement is the capital ratio, quality of productive assets, profitability and cooperative liquidity. The predicate 41 KSP / USP in Gowa Regency which has been analyzed into four financial ratios in table 6 below.

Data Table 6 explains that KSP / USP that are declared healthy are those who already have a capital ratio, earning asset quality, profitability, and liquidity with a score of 81-100. These KSP / USP are those who have capital turnover, efficient management of productive asset quality, receivables are very smooth and profitability and liquidity are very good. Whereas KSP / USP which was declared unhealthy with an appraisal score was below 51 percent and KSP / USP experienced a lot of problem loans, resulting in capital turnover, earning asset quality, noncurrent receivables and low profitability and liquidity. 
Table 5

Awarding 41 KSP / USP titles in Gowa Regency in 2008

\begin{tabular}{cccc}
\hline No. & Predicate & Frequency & $\%$ \\
\hline 1 & Healthy & 13 & 32.0 \\
2 & Healthy enough & 21 & 51.0 \\
3 & Unwell & 4 & 10.0 \\
4 & Not healthy & 3 & 7.0 \\
\hline & total & 41 & 100 \\
\hline
\end{tabular}

Source: Data Processing Results, 2009

If related to the coefficient of determination obtained, the four factors have a contribution of 99.8 percent. The amount of contribution is reasonable because other findings obtained in this study indicate that the average score of the four factors to the performance of KSP / USP in Gowa Regency is 75.00 percent, with the KSP / USP predicate in Gowa Regency quite healthy.

\section{CONCLUSION}

The results of the study using financial ratio analysis and statistical analysis showed that KSP / USP in Gowa Regency were stated to be fairly healthy on average, but 1 ( 7.00 percent) KSP / USP was declared unhealthy out of the $16 \mathrm{KSP} /$ USP studied. This is due to the large number of overdue loans and insufficient capital availability. While the results of statistical analysis showed that the four factors examined had a significant effect both partially and simultaneously at 0,000 each at a 0.05 level of confidence so that the hypothesis was declared accepted.

The magnitude of the correlation coefficient (r) is 0.999. Based on the table of interpretations of the correlation coefficient (r) stated earlier, the influence between capital (X1), quality of productive assets (X2), profitability (X3), and liquidity (X4) on the performance of KSP / USP in Gowa Regency has a category or a very strong relationship level is in the coefficient interval $0.80-1.00$. The coefficient of determination R2 (R square) is 0.998 or 99.8 percent. This means that increasing or decreasing the KSP / USP performance evaluation score in Gowa Regency, 99.8 percent is contributed by capital (X1), earning asset quality (X2), profitability (X3), and liquidity (X4), while the remaining 0,2 percent is the contribution of other variables not used in this study. This is due to the fact that among the five factors used in evaluating cooperative performance, four factors have been included in the research variable, only management factors are not included because management factors are used to assess the health of the administration, while the four factors studied look at being healthy in business.

\section{REFERENCES}

Aumarm, R. J. (2016). Acceptable points in general cooperative n-person games. Contributions to the Theory of Games (AM-40), Volume IV, 40, 287.

Creswell, J. W. (2013). Research Design: Qualitative Approach, Quantitative and Mixed. 
106 Jurnal Administrare: Jurnal Pemikiran Ilmiah dan Pendidikan Administrasi Perkantoran Vol. 7, No. 1, January - June 2020, Pages 93-108

Yogyakarta: Student Library.

Farida, U., Wagiyanto, E., Bustamin, M., \& Salam, R. (2017). Analysis of Empowerment Program that was Implemented in Mamuju Regency East Sulawesi Indonesia. 2nd International Conference on Education, Science, and Technology (ICEST 2017).

Galor, Z., \& Sofer, M. (2019). The reserve fund: Is it a necessary anchor for a successful cooperative? Journal of Co-Operative Organization and Management, 7(2), 100089. https://doi.org/https://doi.org/10.1016/j.jcom.2019.100089

Hadfield-Menell, D., Russell, S. J., Abbeel, P., \& Dragan, A. (2016). Cooperative inverse reinforcement learning. Advances in Neural Information Processing Systems, 3909-3917.

Iliopoulos, C., Värnik, R., Filippi, M., Võlli, L., \& Laaneväli-Vinokurov, K. (2019). Organizational design in Estonian agricultural cooperatives. Journal of Co-Operative $\begin{array}{llll}\text { Organization and } & \text { Management, } & 7(2), & 100093 .\end{array}$ https://doi.org/https://doi.org/10.1016/j.jcom.2019.100093

Iskandar, T., \& Partadiredja, A. G. (1995). Efisiensi relatif dan distribusi pendapatan petani padi berdasarkan sistem penguasaan lahan usaha tani di Daerah Istimewa Aceh. [Yogyakarta]: Universitas Gadjah Mada.

Jensen-Auvermann, T., Adams, I., \& Doluschitz, R. (2018). Trust-Factors that have an impact on the interrelations between members and employees in rural cooperatives. Journal of Co-Operative Organization and Management, 6(2), 100-110. https://doi.org/https://doi.org/10.1016/j.jcom.2018.09.001

Markovic, S., Jovanovic, M., Bagherzadeh, M., Sancha, C., Sarafinovska, M., \& Qiu, Y. (2020). Priorities when selecting business partners for service innovation: The contingency role of product innovation. Industrial Marketing Management, 88, 378-388. https://doi.org/https://doi.org/10.1016/j.indmarman.2020.06.001

Masri, S., \& Effendi, S. (1995). Metode Penelitian Survai, Edisi Revisi. Jakarta: Pustaka LP3ES Indonesia.

Ning, Q., Tao, G., Chen, B., Lei, Y., Yan, H., \& Zhao, C. (2019). Multi-UAVs trajectory and mission cooperative planning based on the Markov model. Physical Communication, 35, 100717. https://doi.org/https://doi.org/10.1016/j.phycom.2019.100717

Pahlavanhoseini, A., \& Sepasian, M. S. (2019). Scenario-based planning of fast charging stations considering network reconfiguration using cooperative coevolutionary approach. Journal of Energy $\quad$ Storage, $23, \quad 544-557$. https://doi.org/https://doi.org/10.1016/j.est.2019.04.024

Ren, Y., Tian, G., Zhao, F., Yu, D., \& Zhang, C. (2017). Selective cooperative disassembly planning based on multi-objective discrete artificial bee colony algorithm. Engineering Applications of Artificial Intelligence, 64, 415-431. https://doi.org/https://doi.org/10.1016/j.engappai.2017.06.025

Rengifurwarin, Z. A., Akib, H., \& Salam, R. (2018). Snapshot of public service quality in the center for integrated business service (CIBS), cooperative micro small and medium 
enterprises (CMSME), Maluku Province, Indonesia. Journal of Entrepreneurship Education.

Schall, L. D., \& Haley, C. W. (1980). Introduction to financial management. McGraw-Hill Companies.

Zhang, M., Qi, Y., Wang, Z., Zhao, X., \& Pawar, K. S. (2019). Effects of business and political ties on product innovation performance: Evidence from China and India. Technovation, 80-81, 30-39. https://doi.org/https://doi.org/10.1016/j.technovation.2018.12.002

Zhou, P., \& Wen, W. (2020). Carbon-constrained firm decisions: From business strategies to operations modeling. European Journal of Operational Research, 281(1), 1-15. https://doi.org/https://doi.org/10.1016/j.ejor.2019.02.050

Zhuang, Y., Huang, H., Sharma, S., Xu, D., \& Zhang, Q. (2019). Cooperative path planning of multiple autonomous underwater vehicles operating in dynamic ocean environment. ISA Transactions, 94, 174-186. https://doi.org/https://doi.org/10.1016/j.isatra.2019.04.012 
108 Jurnal Administrare: Jurnal Pemikiran Ilmiah dan Pendidikan Administrasi Perkantoran Vol. 7, No. 1, January - June 2020, Pages 93-108 